\section{Kære lasere}

Du sidder nu med første udgave af Scandinavian Journal of Sport and Exercise Psychology (SJ SEP), det nye tidsskrift udgivet af Dansk Idrætspsykologisk Forum (DIFO), mellem hænderne. Som markering af DIFOs 25 års jubilæum $i$ 2017 , valgte en enig bestyrelse fejringen som en anledning til, at lancere en nypudset og opdateret vidensplatform. Dette med inspiration fra det hedengangne Sport og Psyke (tidligere tidsskrift udgivet af DIFO), som var en katalysator for det idrætspsykologiske miljø i 90'erne og begyndelsen af 00 'erne. Meget er sket i det idrætspsykologiske miljø i Danmark siden da, men for DIFOs nuværende bestyrelse synes der i Danmark at mangle en samlende platform for idrætspsykologien. Det håber vi at SJ SEP med tiden kan udvikle sig til, ikke mindst ved at formidle ny viden, men også ved at være et samlingssted for forskere og praktikere med idrætspsykologisk interesse i Danmark og Skandinavien. Formålet med SJ SEP er at indsamle og formidle viden og erfaringer mellem forskere, praktikere, atleter, trænere og andre med interesse for idrætspsykologi. SJSEP er en open access journal, hvilket betyder at det er gratis at læse artiklerne og det udgives årligt af DIFO. SJ SEP offentliggør artikler af høj kvalitet fra både elitesport og ikke elitært miljøer gennem to sektioner: 1) En sektion med det formål at formidle forskningsresultater som er relevant for idrætspsykologi i Skandinavien 2) En sektion med det formål at formidle praktiske løsningsforslag på idrætspsykologiske udfordringer.

I en hastigt ændrende verden, med et fleksibelt og pragmatisk forhold til viden, finder vi det vigtigt at skabe et rum for refleksion imellem alle med idrætspsykologisk interesse. Således vil SJ SEP henvende sig både til forskere og studerende inden for universitetet, men også til træneren og atleten på træningsbanerne. Tidsskriftet ønsker således at støtte den allerede stærke udvikling, som sker inden for idrætspsykologien i Danmark og Skandinavien.

Ved at inkludere et Skandinavisk perspektiv vil tidsskriftet række ud til de nationer som Danmark naturligt samarbejder og sammenligner sig med, lande hvor vi endvidere også ser et stærkt potentiale for at dele viden og erfaringer. Derfor vil artikler i SJ SEP kunne forekomme på dansk, svensk, norsk og engelsk.

SJ SEP står fra starten stærkt i form af et dobbelt chefeditor team bestående af Johan Michael Wikman, PhD og Lektor v. Högskolan i Halmstad samt Peter Elsborg, PhD og Post Doc på Steno Diabetes Center Copenhagen. Johan og Peter vil stå for at udstikke retning og sikre et øget kendskab til SJ SEP i hele Skandinavien. Derudover sidder i redaktørgruppen; Astrid Becker-Larsen, Alexander Flattum og Knud Ryom, som assisterer redaktørerne og den daglige drift af tidsskriftet. Af ligeledes vigtig betydning består reviewer-korpset af stærke kapaciteter såsom; Professor Reinhard Stelter (Københavns Universitet), Professor Anne-Marie Elbe (Universität Leipzig), Lektor Kristoffer Henriksen (Syddansk Universitet, Team Danmark), Studielektor Carsten Hviid Larsen (Syddansk Universitet, Team Danmark), Videnskabelig assistent Astrid BeckerLarsen (Syddansk Universitet), Studielektor Niels Nygaard Rossing (Aalborg Universitet) og Post Doc Knud Ryom (Aarhus Universitet). Tidsskriftet efterstræber fuld gennemsigtighed, hvorfor review-kommentar fra selve redigeringsfasen ligges åbent frem på hjemmesiden, så læseren kan få det fulde og nuancerede billede af submission processen. SJSEP gør ligeledes brug af en dobbelt-blinded reviewproces, som sikrer retfærdig og grundig bearbejdning af hver enkelt fremsendt artikel. Kvaliteten er i højsædet og accepterede bidrag vil således være solid viden, hvad enten det er videnskabeligt eller praksisorienteret.

Første nummer som du sidder med nu, er et jubilæumsnummer og dermed en afsluttende salut $i$ anledning af DIFOs 25 års jubilæum. I den anledning har vi bedt hver enkelt tidligere formand i DIFOs historie om at bidrage til tidsskriftets første nummer. Derfor finder du artikler i dette første nummer fra: 1) Reinhard Stelter, formand fra 1994-2004, 2) Kristoffer Henriksen, formand fra 2004-2010, 3) Carsten Hviid Larsen, formand fra 20102012 og 4) Niels Nygaard Rossing, formand fra 2012-2014. Derudover har vi anmodet professor Anne-Marie Elbe, præsidenten for den Europæiske hovedforening inden for idrætspsykologi, FEPSAC, om at bidrage med en artikel. Dermed står bidragsyderne til første nummer af SJ SEP som nogle af de stærkeste kapaciteter det er muligt at samle i vores Danske andedam. Hvorved vi søger at illustrere og påvise for jer læsere, at SJ SEP ambitioner og fremtidige udgivelser vil være af højeste kvalitet. Dermed ligger vi også et pres på redaktørgruppen, men det er et pres vi gerne ligger på os selv, til forhåbentlig glæde og gavn for SJ SEP læsere.

På vegne af DIFO og redaktørgruppen omkring SJ SEP, håber vi at I vil tage vel imod dette nye tiltag. Ligeledes håber vi at mange kunne have lyst til at sende artikelideer til SJ SEP.

Tak til bidragsyderne til dette første nummer og alle $ø v$ rigt involverede i udarbejdelsen. Det er en stor glæde og stolthed at vi endelig kan forløse en langvarig drøm i DIFOregi.

De bedste hilsner

Knud Ryom

Formand DIFO

J ohan Michael Wikman \& Peter Elsborg Editors-in-Chief 